\author{
S. Dyadya, Ye. Kozlova, A. Germashev, V. Logominov, \\ Zaporizhzhia, Ukraine
}

\title{
SIMULATION OF THE MACHINED SURFACE AFTER END MILLING WITH SELF-OSCILLATIONS
}

\begin{abstract}
Thin-walled parts are widely used in the aviation industry. It is mainly carried out with end mills and is accompanied by self-oscillation during rough milling. They negatively affect the quality of the machined surface. Therefore, it is important to model it taking into account the dynamics of the milling process to predict the accuracy. In the early works of the authors, the mechanism of the profile forming of the machined surface was determined. In this case, the identity of the shape of the cutting surface and the oscillogram of part's oscillations during milling is taken as a basis. The first wave of self-oscillations takes part in the shaping of the machined surface during cut-up milling with selfoscillation, and during cut-down milling - the last wave. The change in the distances of the cut depressions to the position of the elastic equilibrium of the part is periodically repeated from the maximum value to the minimum. Based on this, when modeling the waviness pitch of the machined surface after cut-up milling, it is necessary to know the feed rate and how many cuts were made by the tool from the largest to the smallest depression. When modeling the machined surface after cut-down milling, you need to know the length of the cutting surface. It is calculated based on cutting speed and cutting time. The formula for determining the waviness pitch after cut-down milling is derived taking into account the tool feed. The waviness height of the machined surface after cut-up and cut-down milling is determined as the difference between the largest and smallest depressions. To determine the size of the pitch and the height of the waviness, formulas are derived for converting electrical and time values of oscillograms into linear ones. These formulas also allow you to determine areas of the oscillogram with oscillations of the part during cutting and the resulting surface areas on the profilogram. The methods for modeling machined surfaces were tested after cut-up and cut-down milling with self-oscillation. In this case, the pitch and height of the waviness on the profilograms were compared with those calculated from the results of measurements of the oscillograms. Based on their analysis, refined formulas for calculating the waviness height have been derived. The error between the measurements of the waviness pitch and height and the calculated values is within $6 \%$.
\end{abstract}

Keywords: milling; self-oscillation; waviness; pitch; height; cutting surface; modeling.

\section{INTRODUCTION}

The issues of processing accuracy and productivity, regardless of the level of technology development, always remain relevant. This also applies to end milling of thin-walled parts, which are widely used in the products of the aviation industry. Their rough processing falls on the third high-speed zone [1], where selfoscillations act, the intensity of which affects the shape of the machined surface.

The data obtained during the experiments on the mechanisms of formation of the machined surface during end milling with self-oscillations [2-8] make it possible to develop a methodology for its modeling. 
End milling machined surfaces are formed by depressions remaining from the cutting surface when the part is moved. The depression depth $(\Delta)$ is determined by the distance to the elastic equilibrium position of the part (Fig. 1).

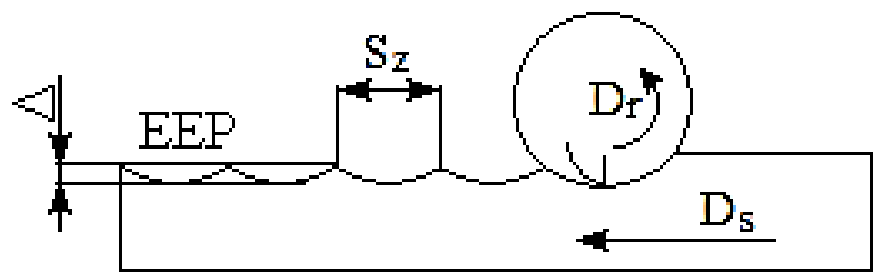

Figure 1 - Diagram for determining the depression depth after end milling

The elastic equilibrium position (EEP) is the position of the part's surface when no driving force is acting on it. If these distances are equal, the machined surface does not have the waviness. This is typical for milling in the first and second high-speed oscillation zones. In the third high-speed zone, the distance of depressions to the EEP periodically changes from the maximum value to the minimum, forming waviness on the machined surface.

The modeling is based on the identity of the cutting surface shape and the oscillogram of the part oscillations during cutting [3]. Therefore, when constructing a model of the machined surface, the data are used, which are determined from the basic fragments of the oscillogram (BFO) [6], taking into account the peculiarities of the cutting processes during cut-up and cut-down milling. With cut-up milling, the workpiece moves to the tool and the forming area is at the beginning of the cutting surface [3,7]. During cut-down milling, the workpiece moves in the direction of the tool rotation and the forming area is at the end of the cutting surface $[2,4,8]$.

\section{MATERIALS AND METHODS}

To simulate the machined surface obtained in the third high-speed oscillation zone after cut-up milling, it is necessary to know the feed per tooth - $S_{z}$ and the number of the mill cuts - $N$, at which the deviation from the EEP of the first selfoscillation wave changes from the maximum value $-\Delta_{\max }$ to the minimum $-\Delta_{\min }$ (Fig. 2). 

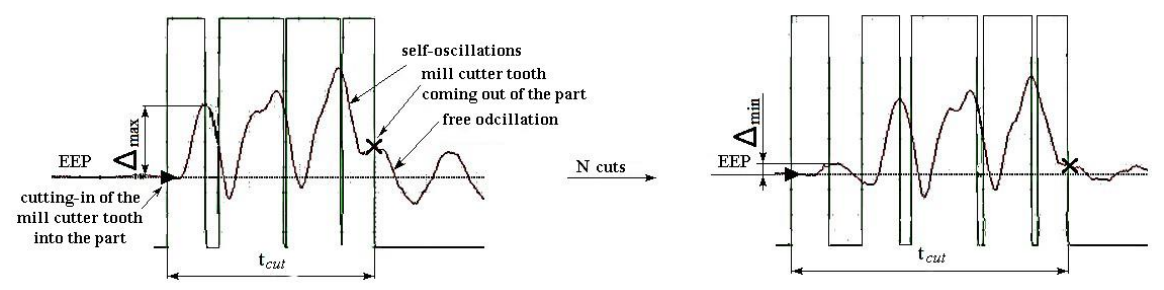

Figure 2 - Change in deviation from EEP of the first wave of self-oscillations during cut-up milling, determined by BFO

The waviness pitch on the machined surface $-S_{w}$ is determined by the formula:

$$
S_{w}=S_{z} N
$$

The waviness height $-W_{z}$ is determined as the difference between the maximum and the minimum values of the deviation from the EEP of the first wave of self-oscillations, within the analyzed cuts:

$$
W_{z}=\Delta_{\max }-\Delta_{\min }
$$

When modeling the machined surface after cut-down milling, it is necessary to take into account the peculiarity that the cutting time $-t_{\text {cut }}$ at each subsequent cut, in the range of variation of the deviation from the EEP of the last self-oscillation wave from the maximum value to the minimum, increases (Fig. 3) [2, 4, 8].
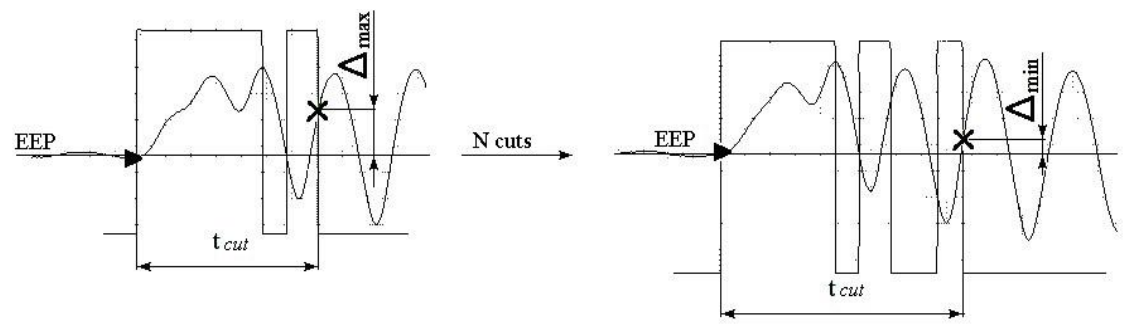

Figure 3 - Change in cutting time and deviation from EEP of the last wave of self-oscillations during cut-down milling

In this case, the length of the cutting surface also increases - $L_{c u t}$, which is calculated by the formula: 


$$
L_{\text {cut }}=\frac{\pi D_{\text {mill }} n}{60} t_{\text {cut }}
$$

where $D_{\text {mill }}$ - cutter diameter, mm;

$n$ - cutter rotation frequency, rpm;

$t_{\text {cut }}-$ cutting time, s.

With cut-down milling, as well as with cut-up milling, each subsequent plunge of the tool into the part occurs after its movement by the amount of feed per tooth $-S_{z}$. But because each subsequent cutting surface is longer than the previous one, the remaining depression from the next cut is in front of the previous one. This order of formation of depressions is periodically repeated. As a result, a wavy profile is formed on the machined surface.

To theoretically determine the waviness pitch during cut-down milling, the following method was used. Since the length of the cutting surface during cutdown milling with self-oscillation periodically changes from the minimum value to the maximum value, the minimum cutting time was chosen as the reference point, according to which, based on formula (3), the minimum cutting surface length is calculated. When the tool leaves it, a depression is cut out, which is the most distant from the EEP. From the minimum length of the cutting surface, the position of the depressions of subsequent cuts is determined to the most distant and closest to the EEP, which will be one of the peaks of the waviness. Next, the position of the next cutting surface with the minimum length is determined, from which the abovementioned constructions are performed, and the next peak is located. The distance between the peaks is equal to the waviness pitch - $S_{w}$ (Fig. 4).

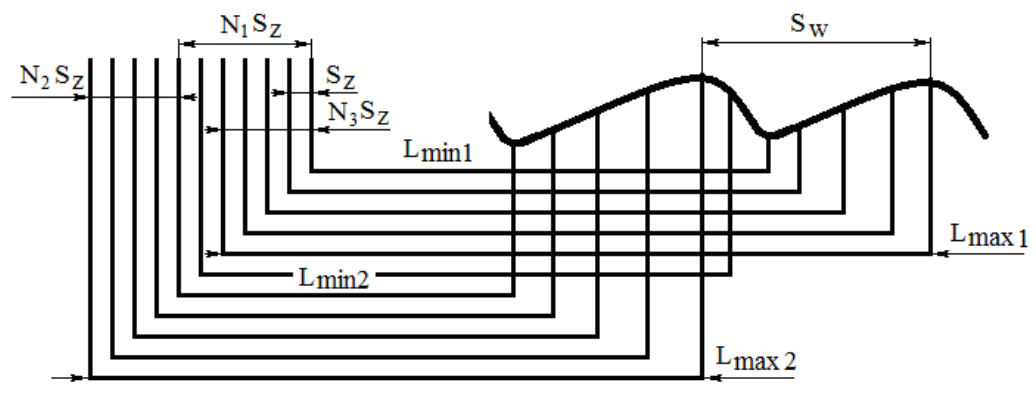

Figure 4 - Diagram for determining the waviness pitch on the machined surface after cut-down milling

The waviness pitch $-S_{w}$, as the distance between adjacent protrusions on the machined surface, calculated by the formula: 


$$
S_{w}=L_{\max 1}-L_{\max 2}+S_{z} \cdot\left(N_{1}+N_{2}-N_{3}\right),
$$

where $L_{\max 1}$ and $L_{\max 2}-$ maximum lengths of cutting surfaces at maximum times of profiling, $\mathrm{mm}$;

$S_{z}$ - feed per tooth, mm;

$N_{l}$ - the number of cuts by the cutter tooth between the minimum lengths of the cutting surfaces;

$N_{2}$ - the number of cuts with the cutter tooth from the minimum length of the cutting surface to the maximum in the area where the current wave is formed;

$N_{3}$ - the number of cuts with the cutter tooth from the minimum length of the cutting surface to the maximum in the area where the previous wave was formed.

The waviness height during cut-down milling, as well as with cut-up milling, is calculated by the formula (2).

To evaluate the proposed method for modeling machined surfaces after end milling, a comparison of the geometric parameters of waviness, determined from the profilograms after milling, and calculated from the parameters of the basic fragments of the oscillograms was carried out. This is possible with the help of analog-to-digital converters and an inductive proximeter XS1M18AB120 when recording oscillograms. Its calibration allows converting electrical and time signals into linear ones. In this case, on the profilograms, the pitch - $S_{w}$ and height $-W_{z}$ of the waviness of the machined surface are calculated by the formulas:

$$
S_{w}=t \cdot v,
$$

where $t$ - time of the signal recording between two adjacent protrusions on the profilogram, $\mathrm{s}$;

$v$ - signal recording speed, determined by the feed of the machine table, $\mathrm{mm} /$ s.

$$
W_{z}=k \cdot V,
$$

where $k$ - calibration value for the XS1M18AB120 inductive proximeter used when recording the profilogram, $\mathrm{mm} / \mathrm{V}$;

$V$ - the greatest deviation of the recorded signal from the EEP, V.

\section{EXPERIMENTS AND RESULTS DISCUSSION}

The studies were carried out in the third high-speed oscillation zone on an experimental stand [6] with a special single-tooth cutter with cutting modes: spindle speed $n_{s p}=280 \mathrm{rpm}$; feed per tooth $S_{z}=0.1 \mathrm{~mm}$; axial depth $a_{p}=3.4 \mathrm{~mm}$; radial depth $a_{e}=0.5 \mathrm{~mm}$, with free cut-up and cut-down milling. 
After milling, profilograms were recorded, fragments of which are shown in Fig. 5.

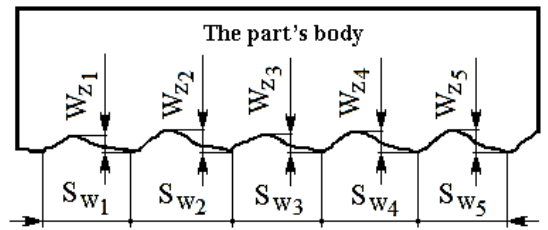

a

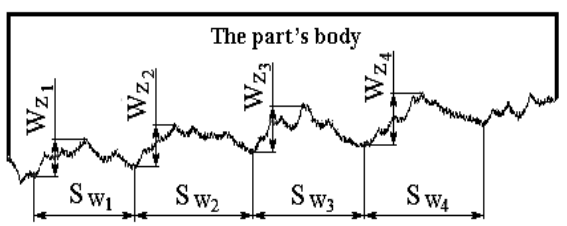

b

Figure 5 - Fragments of profilograms after cut-up (a) and cut-down (b) milling

The unique ability to digitize the signal allows using the formula (5) on the oscillogram to find the base fragments corresponding to the formation of the surface recorded on the profilogram.

On the basis of this and according to the methods described above, models of the machined surfaces were built after cut-up and cut-down milling (Fig. 6).

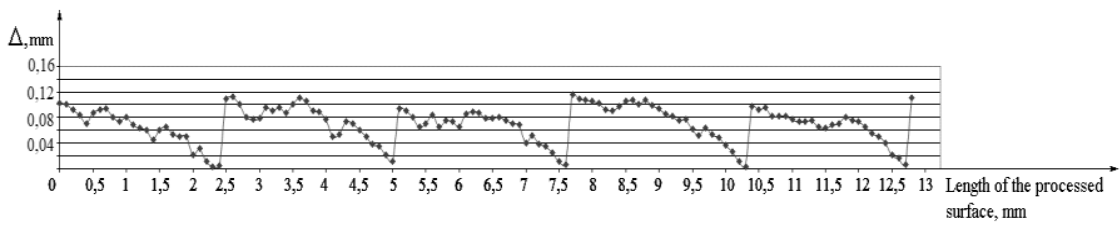

a

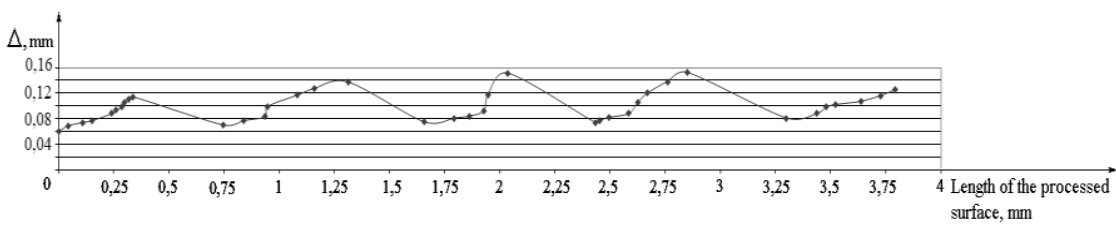

b

Figure 6 - Models of machined surfaces after cut-up (a) and cut-down (b) milling

It should be noted that due to the radius of the tip of the indicator clock in the device for recording profilograms [6], the most distant depressions on the machined surface are not recorded. Therefore, instead of formula (2), when determining the waviness height $-W_{z i}$ more than $0.07 \mathrm{~mm}$ using oscillograms, formula (7) is used, and with waviness height up to $0.07 \mathrm{~mm}$ - formula (8): 


$$
\begin{aligned}
& W_{z i}=-4,6334 \cdot \Delta_{i}^{2}+2,1319 \cdot \Delta_{i}-0,0746, \\
& W_{z i}=-17,387 \cdot \Delta_{i}^{2}+2,9825 \cdot \Delta_{i}-0,071 .
\end{aligned}
$$

where $\Delta_{\mathrm{i}}$ - the difference between the max and min deviation of the wave (the first one for cut-up milling and the last one for cut-down milling) of selfoscillations from the EEP on the oscillogram within the change period, $\mathrm{mm}$.

Table 1 and 2 show the values of the pitch and the height of the waviness of the machined surface after cut-up milling. Table 3 and 4 - after the cut-down milling.

Table 1 - The waviness pitch of the machined surface, determined from profilograms and calculated by the formula (1)

\begin{tabular}{|l|c|c|c|c|c|}
\hline $\begin{array}{l}\text { Section number on the profilogram } \\
\text { (Fig. 5, a) }\end{array}$ & 1 & 2 & 3 & 4 & 5 \\
\hline $\begin{array}{l}\text { The waviness pitch, } \mathrm{S}_{\mathrm{w}} \text { on the } \\
\text { profilogram, mm }\end{array}$ & 2.54 & 2.65 & 2.57 & 2.65 & 2.49 \\
\hline Number of cuts with a cutter tooth, $N_{3}$ & 25 & 26 & 26 & 27 & 24 \\
\hline Feed per tooth, $S_{z}, \mathrm{~mm}$ & \multicolumn{5}{|l|}{0.1} \\
\hline $\begin{array}{l}\text { The waviness pitch } S_{w}, \text { calculated by } \\
\text { the formula }(1), \mathrm{mm}\end{array}$ & 2.5 & 2.6 & 2.6 & 2.7 & 2.4 \\
\hline Error, \% & 1.57 & 1.89 & 1.15 & 1.85 & 3.61 \\
\hline
\end{tabular}

Table 2 - The waviness height, measured on the profilogram and calculated by the formula (6)

\begin{tabular}{|l|c|c|c|c|c|}
\hline $\begin{array}{l}\text { Section number on the profilogram } \\
\text { (рис. 5, a) }\end{array}$ & 1 & 2 & 3 & 4 & 5 \\
\hline $\begin{array}{l}\text { The waviness height on the } \\
\text { profilogram, } W_{z i}, \mathrm{~mm}\end{array}$ & 0.083 & 0.091 & 0.083 & 0.107 & 0.082 \\
\hline $\begin{array}{l}\text { The difference between the max and } \\
\text { min deviation of the first wave of } \\
\text { self-oscillations from the EEP, } \Delta_{\mathrm{i}} \mathrm{mm}\end{array}$ & 0.092 & 0.103 & 0.091 & 0.112 & 0.094 \\
\hline $\begin{array}{l}\text { The waviness height } W_{z i}, \text { calculated } \\
\text { by formula (6), mm }\end{array}$ & 0.082 & 0.095 & 0.081 & 0.106 & 0.084 \\
\hline Error, \% & 1.2 & 4.21 & 2.4 & 0.93 & 2.38 \\
\hline
\end{tabular}


Table 3 - The waviness pitch, measured on the profilogram and calculated by the formula (4)

\begin{tabular}{|l|c|c|c|c|}
\hline $\begin{array}{l}\text { Section number on the profilogram } \\
\text { (рис. 5, b) }\end{array}$ & 1 & 2 & 3 & 4 \\
\hline $\begin{array}{l}\text { The waviness pitch on the profilogram } \\
S_{w i}, \mathrm{~mm}\end{array}$ & 0.768 & 0.902 & 0.809 & 0.92 \\
\hline $\begin{array}{l}\text { The waviness pitch } S_{w i} \text {, calculated by } \\
\text { formula (4), mm }\end{array}$ & 0.75 & 0.91 & 0.77 & 0.87 \\
\hline Error, \% & 2.34 & 0.88 & 4.82 & 5.43 \\
\hline
\end{tabular}

Table 4 - The waviness height, determined from the profilogram and calculated by the formula (7)

\begin{tabular}{|l|c|c|c|c|}
\hline $\begin{array}{l}\text { Section number on the profilogram } \\
\text { (рис. 5, b) }\end{array}$ & 1 & 2 & 3 & 4 \\
\hline $\begin{array}{l}\text { The waviness height } W_{z i} \text {, measured on } \\
\text { profilogram, mm }\end{array}$ & 0.040 & 0.048 & 0.052 & 0.055 \\
\hline $\begin{array}{l}\text { The difference between the max and } \\
\text { min deviation of the last wave of self- } \\
\text { oscillations from the EEP, } \Delta_{\mathrm{i}} \mathrm{mm}\end{array}$ & 0.054 & 0.067 & 0.075 & 0.078 \\
\hline $\begin{array}{l}\text { The waviness height } W_{z i}, \text { calculated by } \\
\text { formula (7), mm }\end{array}$ & 0.039 & 0.051 & 0.055 & 0.056 \\
\hline Error, $\%$ & 2.5 & 5.9 & 5.45 & 1.78 \\
\hline
\end{tabular}

The errors of the models of the machined surfaces, built according to the shape-generating parameters of the oscillograms, after the cut-up and cut-down milling, in comparison with the profilograms, do not exceed $6 \%$.

\section{CONCLUSIONS}

Methods for constructing the profile of the machined surface after cut-down and cut-up milling with self-oscillations are proposed. It is based on the identity of the shape of the cutting surface and the oscillogram of the part's oscillations. Based on this, the shaping parameters from the oscillograms are used to build a model of the machined surface. The calculated values of the pitch and height of the waviness on it are close to those measured on the profilograms. Building a model of a machined surface based on BFO data allows one to predict the effect of cutting conditions and tool geometry on it.

References: 1. Vnukov Yu.N, Dyadya S.I, Kozlova Ye.B, Logominov V.A, Chernovol N.N. Self-oscillations when milling thin-walled elements of workpiece s. Zaporizhzhia: ZNTU; 2017. 208 p. 
2. Svinin V.M. Milling with modulated cutting speed. ed. A.I. Promtova. Irkutsk: Publishing house Ir: TTU; 2007. 304 p. 3. Shapoval Yu.V, Zaloga V.O. Improving the efficiency of machining parts by control the dynamics of the turning process with high spindle speeds. BULLETIN OF ZhSTU; 2017. 2 (80). pp. 175-184. DOI: https://doi.org/10.26642/tn-2017-2(80)-175-184 pp. 175-184. 4. Tashlitsky N.I. Primary source of energy for excitation of self-oscillations when cutting metals. Bulletin of mechanical engineering. 1960. 2. pp. 10-20. 5. Mazur N.P, Vnukov Yu.N, Grabchenko A.I. and others. Osnovy teorii rezaniya materialov, NTU KhPI, Kharkiv. 2003. 534 p. 6. Zharkov I.G. Vibrations during processing with a blade tool. Mechanical Engineering, 1986. 184 p. 7. Dyadya S.I. Investigation of the formation of the machined surface of a thin-walled element of the workpiece during end cylindrical milling with self-oscillations. Modern Technologies in Machinery. 2017;12: pp. 5-18. 8. Hung C.Y, Junz J.J. Wang Effects of cutting conditions on dynamic cutting factor and process damping in milling. Internation jornal of Machine Tools and Manufacture. 51, 2011. pp. 320-330.

\title{
Сергій Дядя, Олена Козлова, Антон Гермашев, Віктор Логомінов, Запоріжжя, Украіна \\ МОДЕЛЮВАННЯ ОБРОБЛЕНОЇ ПОВЕРХНІ ПІСЛЯ КІНЦЕВОГО ФРЕЗЕРУВАННЯ З АВТОКОЛИВАННЯМИ
}

\begin{abstract}
Анотація. В авіаційній промисловості широко поширена обробка тонкостінних деталей. Переважно вона виконується кінцевими фрезами $і$ при чорновому фрезеруванні супроводжується автоколиваннями. Вони негативно виливають на якість обробленої поверхні. Тому важливим є ї̈ моделювання з урахуванням динаміки процесу фрезерування для прогнозування точності. У ранніх роботах авторів визначено механізм формування профілю обробленої поверхні. При цьому за основу взята ідентичність форми поверхні різання і осцилограми коливань деталі при фрезеруванні. У формоутворенні обробленої поверхні при зустрічному фрезеруванні з автоколиваннями бере участь перша хвиля автоколивань, при попутному фрезеруванні - остання хвиля. Зміна відстаней вирізаних западин до положення пружної рівноваги деталі періодично повторюється від найбільшого значення до найменшого. На підставі иього, при моделюванні кроку хвилястості обробленої поверхні після зустрічного фрезерування, необхідно знати величину подачі $i$ кількість різів, щзо зроблено інструментом від найбільшої до найменшої западини. При моделюванні обробленої поверхні після попутного фрезерування треба знати довжсину поверхні різання. Вона розраховується на підставі швидкості різання $і$ часу формування поверхні різання. Формула для визначення кроку хвилястості після попутного фрезерування отримана з урахуванням подачі інструменту. Висота хвилястості обробленої поверхні після зустрічного і попутного фрезерування визначається як різничя між найбільшою $і$ найменшою западинами. Для визначення розмірів кроку і висоти хвилястості отримано формули по перетворенню електричних $і$ часових величин осцилограм в лінійні. Ці формули також дозволяють визначати ділянки осцилограми з коливаннями деталі при різанні і отримані при цьому ділянки поверхні на профілограмі. Методики моделювання оброблених поверхонь перевірялися після зустрічного і попутного фрезерування з автоколиваннями. При иьому порівнювалися крок $i$ висота хвилястості на профілограмі і розраховані за результатами вимірювань осиилограм. На підставі їх аналізу виведені уточнені формули для розрахунку висоти хвилястості. Похибка між результатами вимірювань кроку і висоти хвилястості і розрахованими значеннями знаходиться в межсах $6 \%$.
\end{abstract}

Ключові слова: фрезерування; автоколивання; хвилястість; крок; висота; поверхня різання; моделювання. 